\title{
Status Free Trade Zone Kota Batam Dalam Persepktif Ekonomi Pertahanan
}

\author{
Diky Budiman \\ Manajemen Kepelabuhan dan Pelayaran, Universitas Karimun \\ Email: budiman.diky@gmail.com
}

\begin{abstract}
This study aims to understand the condition of Batam City with the status of free trade zone and also to look at the achievement of that status with economic defense persepctive. This study used qualitative method. The result is Batam City with the status of free trade zone are changed such as their rules, the facilities of infrastructure to support the status, while Batam's economic growth has so far remained stagnant, investment in foregin direct investment has been achived as expected, but must be observed so that there is no dependence on foreign parties. Exports have decreased, while import have increased, export and import activites of Batam City are depended on the port system, while the exsiting system is still not good. In addition, the growth of labour is not accordance with the amount of employment available in Batam City, it is feard to be a threat.
\end{abstract}

Keywords: Free Trade Zone; Economic Defense; Batam City

\begin{abstract}
Abstrak. Penelitian ini bertujuan untuk mengetahui kondisi Kota Batam dengan adnaya status free trade zone serta pencapaian status free trade zone Kota Batam dalam perspektif ekonomi pertahanan. Metode yang digunakan adalah metode kualitatif dengan analisis data model interaktif. Hasil yang diperoleh adalah kondisi Kota Batam dengan adanya status free trade zone terus mengalami perubahan dari segi aturan, hingga fasilitas infrastruktur yang ada guna mendukung status free trade zone, sedangkan pertumbuhan ekonomi Kota Batam sejauh ini masih stagnan, investasi dalam bentuk foreign direct investment telah tercapai sesuai harapan namun harus di perhatikan agar tidak ada ketergantungan dengan pihak asing, untuk ekspor mengalami penurunan sedangkan impor mengalami peningkatan, kegiatan ekspor dan impor Kota Batam masih bergantung pada sistem pelabuhan, sedangkan sistem yang ada masih belum baik. Pertumbuhan tenaga kerja yang masuk masuk tidak sesuai dengan besarnya lapangan kerja yang tersedia di Kota Batam, hal tersebut dikhawatirkan menjadi ancaman.
\end{abstract}

Kata Kunci: Free Trade Zone; Ekonomi Pertahanan; Kota Batam

\section{PENDAHULUAN}

Kota Batam merupakan salah satu Kota yang memiliki keunggulan dari letak geografis yang cukup strategis yaitu berada pada Selat Malaka yang merupakan salah satu jalur perdagangan dunia. Sejak tahun 1969, Kota Batam mendapatkan perhatian khusus dari Pemerintah Pusat, seperti penetapan free trade zone area yang tertuang dalam UndangUndang Nomor 44 tahun 2007 tentang Kawasan Bebas dan Pelabuhan Bebas. Penetapan kawasan tersebut pada dasarnya untuk menindaklanjuti Memorandum of Understanding antara Indonesia dan Singapura dalam kerjasama bidang ekonomi.
Free Trade Zone (FTZ) Kota Batam, dilaksanakan oleh badan khusus pemerintah yang dikenal dengan nama Badan Pengusahaan (BP) Batam, yang bertugas dalam penyelenggaraan pengembangan Kawasan Bebas dan Perdagangan Bebas sesuai kewenangan yang diberikan, berdasarkan Surat Keputusan Dewan Kawasan Nomor 3 tahun 2008 tentang Badan Pengusahaan Kawasan Perdagangan Bebas dan Pelabuhan Bebas Batam.

Dalam kawasan FTZ ini beberapa hambatan seperti tarif dan kuota dihapuskan dengan tujuan mempermudahurusan birokrasi 
dan menarik investor-investor baru untuk berinvestasi di kawasan FTZ (Anwar, 2014).

$$
\text { Selain menghilangkan hambatan }
$$

perdagangan, pengembangan kawasan perdagangan bebas dan pelabuhan bebas merupakan salah satu instrument yang dipersiapkan pemerintah untuk meningkatkan nilai ekonomis suatu wilayah, baik segi kegiatan industri, ekspor- impor, investasi dan segala bentuk kegiatan perekonomian yang memiliki efek pengganda (multiplier effect). Begitu juga dengan Kota Batam yang diharapkan mampu memberikan multiplier effect tidak hanya bagi pengembangan perekonomian provinsi Kepri tetapi juga kepada Indonesia secara umum.

Penetapan FTZ Kota Batam, selain memberikan efek positif, tentunya juga memiliki sisi negatif yang bisa menjadi ancaman. Sisi negatif dari penetapan suatu kawasan perdagangan bebas dapat diaktegorikan kedalam dua bagian. Pertama, sisi negatif kurang berbahaya, dimana jika persoalan tersebut hanya fokus pada permasalahan transfer modal, fasilitas yang diberi kepada investor, maupun persaingan dengan investor lokal. Kedua, sisi negatif sangat berbahaya jika investor menekan suatu negara atau campur tangan dalam urusan negara yang dijanjikan untuk menerima modal (Yealta, 2015). Berdasarkan kedua sisi negatif tersebut dapat dapat diketahui bahwa aturan yang sangat jelas harus dibuat oleh Pemerintah Kota dan BP Batam yang menjadi pelaksana, terkait penerapan FTZ.

Kawasan bebas seperti yang di jelaskan dalam Specific Annex D of The Revised Kyoto Convention (RKC) 1999 dalam Zaenuddin (2012), bahwa "free zone" means a part of the territory of a Contarcting Party any goods introduced are generally regarded, insofar as import duties and taxes are concerned as being, outside the Customs territory. Berdasarkan pengertian diatas, dapat dilihat bahwa kota Batam, telah memenuhi konsep kawasan bebas dimana segala bentuk barang yang masuk ke kota Batam dianggap di luar daerah pabean. Hal ini dilakukan, tentunya sebagai bentuk langkah pemerintah dalam memanfaatkan letak kota Batam yang strategis. Adanya status FTZ inilah, yang menjadikan kondisi kota Batam terus mengalami perubahan, serta terus berkembang pesat jauh diatas kota- kota lain di Indonesia, khususnya di provinsi Kepri. Adanya kemudahan-kemudahan yang diberikan menjadikan investor asing melirik kota Batam untuk menanamkan modalnya.

Kota Batam yang letaknya yang sangat strategis menjadikan Kota Batam menjadi incaran bagi pihak asing. Dengan harapan agar penelitian ini, bisa memberikan gambaran secara jelas bagaimana dampak positif yang dihasilkan dari pembentukan FTZ Kota Batam, serta adanya perhatian Pemerintah Pusat dalam perkembangan Kota Batam khususnya dari faktor ekonomi pertahanan sehingga adanya kejelasan status FTZ kota Batam, yang nantinya bisa dijadikan landasan oleh seluruh stakeholders kota Batam, khususnya sebagai fokus perkembangan ekonomi Kota Batam. Berdasarkan latar belakang yang dikemukakan maka penuelitian ini berfokus pada status free trade zone (FTZ) kota Batam dalam perspektif ekonomi pertahanan.

\section{METODOLOGI PENELITIAN}

Penelitian ini di lakukan dengan menggunakan metode penelitian kualitatif. Penggunaan pendekatan kualitatif biasanya digunakan untuk mempelajari suatu fenomena secara mendalam. 5 Fungsi utama dari pendekatan kualitatif digunakan untuk menganalisis data yang bersifat kualitatif atau tidak dapat dinominalkan. Creswell (2010) mengemukakan bahwa dalam metode penelitian kualitatif peneliti tidak membawa individu atau kelompok ke dalam laboratorium, dan tidak pula membagikan instrument-instrumen kepada mereka. Informasi yang dikumpulkan dengan berbicara langsung kepada orang-orang dan melihat mereka bertingkah laku dalam konteks natural. Peneliti adalah instrument kunci karena dia akan mengumpulkan data melalui dokumentasi, observasi perilaku, atau melakukan wawancara (Creswell, 2010). Analisa data penelitian ini menggunakan model analisis data dari Miles dan Hubermen (2014) yang disebut dengan Analisa Data Model Interaktif, yang meliputi kondensasi data (data condensation), penyajian data (data display), dan penarikan kesimpulan atau verifikasi (conclusion/veryfing).

\section{HASIL DAN PEMBAHASAN}

\section{Kondisi Kota Batam Dengan Adanya Status Free Trade Zone}

Letak Kota Batam yang strategis yaitu berada pada selat Malaka yang merupakan salah satu jalur perdagangan dunia, menjadikan pengembangan industri di kawasan kota Batam 
cukup berkembang. Perkembangan industri Kota Batam sudah dimulai sejak tahun 1969, letaknya yang berdekatan dengan Singapura dan Malaysia menjadikan kota Batam kemudian bertransformasi menjadi kota berbasis logistik untuk industri minyak dan gas bumi. Kondisi kota Batam terus berubah dari segi Peraturan Daerah hingga berbagai aturan- aturan yang langsung diberikan dari Pemerintah Pusat, seperti aturan status kota Batam yang pada awalnya hanya tempat untuk basis logistik minyak lepas pantai menjadi status Bonded warehouse, hingga status Free trade Zone.

Kondisi kota Batam saat ini memiliki keistimewaan atas kebebasan tarif dan bea masuk, hal ini sesuai dengan peraturan pemerintah yang tertuang dalam Undangundang Nomor 44 tahun 2007 tentang kawasan perdagangan bebas dan pelabuhan bebas atau yang dikenal dengan status free trade zone, yang mana memiliki area bebas untuk sektor perdagangan. 8 Kawasan perdagangan bebas dan pelabuhan bebas kota Batam merupakan salah satu daya tarik yang ditawarkan oleh pemerintah kepada investor asing agar menanamkan modalnya di Kota Batam.

Kondisi kota Batam dengan adanya status FTZ banyak mengalami banyak perubahan, dari segi fasilitas bandara yang berstandar internasional, perluasan pelabuhan untuk bersandarnya kapal-kapal asing, hingga infrastruktur seperti pembangunan jalan tol dan jembatan layang, yang semuanya di persiapkan dalam rangka mendukung status FTZ tersebut. Pemerintah melalui BP Batam, juga terus melakukan pengkajian- pengkajian terhadap status FTZ kota Batam, hal tersebut dilakukan melalui pertemuan- pertemuan yang dilakukan dengan jajaran Pemerintah Kota Batam dan Muspida Kepri. Lebih jauh lagi, Pemerintah Pusat sedang berupaya membuat aturan- aturan baru untuk kawasan Batam, yang mana akan menjadikan status Batam berubah dari FTZ menjadi Kawasan Ekonomi Khusus (KEK), serta melakukan pembahasan terkait fasilitasfasilitas khusus yang akan diberikan terkait Kawasan Ekonomi Khusus kota Batam. Banyaknya aturan hukum yang memayungi kota Batam, dari peraturan daerah hingga Undang-undang menjadikan kondisi di kota Batam, berbeda dari kota-kota lain pada umumnya, terlebih letak kota Batam yang sangat strategis.

Melihat kondisi kota Batam yang terus berkembang, menjadikan aturan hukum yang ada di kota Batam, harus memiliki aturan baku yang khusus, tidak cukup hanya dengan aturan hukum yang biasa, hal ini dikarenakan pengembangan kota Batam, selain mengandung unsur pengembangan ekonomi tetapi juga harus disertakan pertahanan di dalamnya. Menurut Yusgiantoro (2014) bahwa saat ini, wilayah perbatasan tidak dapat lagi dikatakan halaman belakang dari suatu negara, tetapi merupakan halaman terdepan yang harus terus di tumbuh kembangkan sebagai gerbang terdepan suatu Negara. Untuk itu, kota Batam yang berada tepat di perbatasan Negara yang memiliki keistimewaan status yakni FTZ, harus benarbenar diperhatikan. Hal ini sejalan dengan langkah yang diambil mantan danlanal kota Batam, yang menjadikan Pulau Nipah sebagai pangkalan militer, hal ini merupakan bentuk pengamanan yang tepat agar pengembangan kota Batam kedepannya baik status FTZ maupun KEK yang sedang direncanakan bisa berjalan dengan baik.

\section{Pencapaian Status Free Trade Zone Terhadap Pertumbuhan Ekonomi Kota Batam}

Ada berbagai indikator pertumbuhan ekonomi yang bisa digunakan untuk melihat capaian dari penetapan status Free trade Zone Kota Batam, salah satunya adalah pertumbuhan eknomi regional yang bisa dilihat melalui nilai PDRBnya. Berdasarkan data PDRB Kota Batam, diketahui bahwa Kota Batam mencapai pertumbuhan ekonomi sekitar 7\%, capaian tersebut menjadikan Kota Batam dengan pencapaian pertumbuhan ekonomi tertinggi jika dibandingkan dengan kota-kota lain di Indonesia, namun pemerintah pusat beranggapan bahwa tingkat capaian pertumbuhan ekonomi Kota Batam masih bisa diatas angka tersebut, pertumbuhan ekonomi kota Batam bisa saja mencapai target yang tinggi, seperti $12 \%$ sampai $13 \%$ apabila adanya kerja sama antar seluruh elemen penyelenggara Free trade Zone Kota Batam. Selain kerjasama antar seluruh elemen pemerintahan di Kota Batam ada hal lain yang bisa menjadi pembanding kenapa capaian Free trade Zone Kota Batam masih stagnan, menurutnya jika dibandingkan dengan pelabuhan Iskandarsyah di Malaysia, yang menerapkan sistem free trade zone bisa lebih maju dan cepat perekembangannya dikarenakan penangananya langsung di tangani oleh Perdana Menteri. Selain Malaysia, banyak Negara lain seperti Tiongkok, yang juga menerapkan free trade 
zone namun capaiannya bisa meningkat tajam karena langsung diatur oleh Presiden atau Perdana Menteri. Hal ini berbeda dengan Free trade Zone Kota Batam yang memiliki birokrasi yang banyak melibatkan berbagai tingkat pemerintahan, sehingga free trade zone Kota Batam dibawah BP Batam agak sulit untuk berkembang.

Oleh karena itu, pengembangan nilai ekonomis Kota Batam dengan meletakkan keistimewaan yaitu free trade zone bisa dikatakan bentuk yang tepat, investasai sebagai salah satu indikator pertumbuhan ekonomi bisa tercipta, tidak hanya investasi dari dalam negeri tetapi juga investasi dari luar negeri. Namun, perlu diperhatikan juga, bahwa pertumbuhan ekonomi tersebut akan sangat sulit berkembang jika tidak ada sinergitas antar birokrasi pemerintah daerah maupun antara daerah dengan pusat dalam hal pengelolaan status free trade zone tersebut. Untuk melihat capaian status free trade zone secara lebih spesifik, bisa dilihat dari beberapa indikator pertumbuhan ekonomi berikut;

\section{Investasi}

Pada dasarnya penetapan kekhususan status pada suatu daerah atau kota adalah bertujuan untuk meningkatkan investasi pada daerah atau kota tersebut, serta umumnya adalah untuk meningkatkan investasai dalam bentuk penanaman modal asing atau foreign direct investment (FDI). Sunaryah (2010), menyebutkan bahwa investasi adalah penanaman modal untuk untuk satu atau lebih aktiva yang dimiliki dan biasanya berjangka waktu lama dengan harapan mendapatkan keuntungan dimasa yang akan datang. Pada Kota Batam, investasi yang jelas bisa dilihat adalah meningkatnya investasi dalam bentuk penanaman modal asing oleh perusahaanperusahaan multinasional yang kebanyakan bekerjasama dengan Singapura, tentunya investasi ini tidak hanya untuk jangka pendek (5 tahun hingga 10 tahun) tapi biasanya menurut data, investasi yang ada di Kota Batam bisa mencapai puluhan tahun atau jangka panjang. Seperti pendirian perusahaanperusahaan atau investasai asing dalam bentuk real assets yang mampu menarik banyak tenaga kerja, baik dari luar Negeri maupun tenaga kerja lokal atau dalam Negeri. Sedangkan

Ditetapkannya status free trade zone di Kota Batam menjadikan investasi dalam bentuk penanaman modal asing ikut meningkat, terkait hal tersebut, BP batam selaku badan yang melaksanakan free trade zone memprediksi bahwa investasi tersebut akan terus tumbuh secara siginfikan. Berdasarkan hal tersebut, BP Batam telah menyiapkan berbagai fasilitas pendukung terkait mobilitas kendaraan muatan berat, yang akan digunakan untuk pengiriman barang antar pelabuhan yaitu pembagunan jalan tol yang dikhususkan hanya untuk mobil angkutan bermuatan berat yang khusus digunakan untuk barang-barang antar pelabuhan, hal tersebut diharapkan dapat mempercepat arus lalu lintas barang, yang nantinya akan meningkatkan efektifitas dan efisiensi di Kota Batam.

Masuknya investasi ke Indonesia terbagi kedalam dua bagian, yaitu Foreign Direct Investment dan Domestic Direct Investment. Dari kedua jenis investasi tersebut, penanaman modal asing atau Foreign Direct Investment memiliki kontribusi yang lebih besar, terhadap pertumbuhan PDB Indonesia. Hal tersebut bisa menggambarkan pertumbuhan investasi pada kota-kota lain, khususnya kota Batam yang memiliki keistimewaan yaitu free trade zone. Hal ini sejalan dengan pertumbuhan investasi Kota Batam, setelah adanya status free trade zone, dimana pertumbuhan penanaman modal asing atau Foreign Direct Investment mengalami pertumbuhan yang signifikan. Hal tersebut sesuai dengan data yang diperoleh peneliti, yang menunjukkan bahwa pertumbuhan investasi dalam bentuk PMA jauh lebih besar dari pada investasi dalam Negeri. Adanya status free trade zone menyebabkan banyaknya negara asing menanamkan modalnya ke Kota Batam.

Jika dilihat dari segi ekonominya, hal ini tentu sangat menguntungkan bagi kota Batam, melihat data tingginya pertumbuhan penanaman modal asing (foreign direct investment) Batam yang cukup signifikan, maka dengan adanya status free trade zone, maka salah satu indikator pertumbuhan ekonomi yaitu investasi telah tercapai. Sedangkan dari segi pertahanan, Kota Batam sebagai salah satu Kota yang berada di daerah perbatasan tentunya akan ada efek positif dan negatifnya, untuk efek positif, tentunya hal tersebut akan menjadi modal pertahanan yang baik bagi kota Batam. Masuknya investasi asing di Kota Batam tentunya akan membuat banyak kepentingan asing di Kota Batam, maka ancaman dan serangan dalam bentuk perang akan bisa dihindari, karena banyaknya kepentingan asing di kota Batam. 
Dilihat dari segi negatifnya, investasi dalam bentuk penanaman modal asing (foreign direct investment) yang lebih besar dari pada investasai dalam negeri (domestic direct investment) maka ditakutkan kota Batam akan mengalami ketergantungan pada pihak asing, untuk itu investasi yang masuk harus benarbenar melalui pertimbangan yang matang, seperti contoh investasi yang masuk harus memiliki komitmen yang jelas, dari segi izin kepemilikan dalam bentuk surat berharga (financial asset) maupun aktiva tetap (real assets).

\section{Ekspor-Impor}

Letak Kota Batam yang cukup stratetgis, yakni terletak pada jalur perdagangan dunia yaitu Selat Malaka, menjadikan berbagai kegiatan ekspor dan impor banyak dilakukan di Kota Batam. Barang- barang yang di ekspor dan di impor melalui Kota Batam lebih banyak menggunakan jasa pelabuhan, selain itu pelabuhan Kota Batam tidak hanya untuk ekspor dan impor khusus Kota Batam, tetapi juga dimanfaatkan oleh Kabupaten/Kota lainnya di Kepulauan Riau. Pertumbuhan ekonomi dari aspek pengeluaran dipengaruhi oleh beberapa faktor diantaranya investasi, konsumsi, pengeluaran pemerintah, ekspor dan impor. Ekspor merupakan barang dan jasa yang diproduksi di dalam negeri yang kemudian dijual secara luas di luar negeri (Mankiw, 2006).

Kota Batam, saat ini memiliki tingkat ekspor yang besar untuk industri galangan kapal dan industri pendukung pertambangan, menyusul industri komponen elektronik seperti komputer, handphone dan alat-alat elektronik lainnya. Sedangkan untuk alat pertahanan yang di ekspor melalui Kota Batam baiknya adalah dalam bentuk komponen-komponen pendukung, seperti alat perelengkapan pada kapal perang atau kapal patroli, yang memiliki fungsi dual technological seperti drone atau pesawat tanpa awak yang berfungsi sebagai pengintai atau mengukur kondisi cuaca. Negara utama yang menjadi tujuan utama dari barang ekspor Batam adalah singapura, hal ini dikarenakan letak antara Kota Batam dan Singapura yang berdekatan dan sangat stratetgis. Oleh sebab itu, konteks ekspor yang memproduksi barang di dalam negeri kemudian akan dijual secara luas di luar negeri, sangat tepat dalam memanfaatkan lokasi Batam yang sangat strategis yakni berdekatan dengan Singapura dan terletak di jalur perdagangan dunia. Berdasarkan data yang diperolah, Singapura adalah negara yang menjadi tujuan utama dari kegiatan ekspor Kota Batam. Pemanfaatan ekspor melalui Kota Batam akan mempercepat tidak hanya pertumbuhan ekonomi tetapi juga bisa dimanfaatkan untuk ekspor produk-produk pertahanan, lebih jauh lagi produk pertahanan yang baik di produksi dan di ekspor di Kota Batam adalah produk pertahanan yang berbentuk komponen pendukung seperti bagian-bagian dari kapal perang atau kapal patroli.

Kegiatan impor yang masuk ke Kota Batam sampai saat ini masih bersifat konsumtif hal ini disebabkan karena permintaan yang masuk melalui Batam sangat dipengaruhi oleh permintaan dari tingkat konsumen itu sendiri, seperti pada pakaian fashion, handphone dan produk-produk pertanian. Permasalahan yang sering di temukan adalah impor pakaian yang masuk adalah impor pakaian bekas yang sebenarnya sudah dilarang untuk masuk melalui Kota Batam. Biasanya impor ini lebih banyak melalui pelabuhan- pelabuhan yang ada di Kota Batam, hal ini dikarenakan mudahnya kapalkapal yang masuk ke Batam karena selain adanya status free trade zone yang cukup memudahkan kegiatan jual beli dalam bentuk impor di Batam, regulasi impor di Batam juga tergolong cukup mudah. Sedangkan impor untuk alat-alat pertahanan sejauh ini masih pada tingkatan alat kelengkapan kapal patrol seperti radar navigasi dan kelengkapan militer lainnya yang masih berada pada skala yang rendah.

\section{Tenaga Kerja}

Pertumbuhan ekonomi suatu Kota tidak akan lepas dari tingkat tenaga kerja yang ada pada Kota tersebut, seperti halnya Kota Batam, yang memiliki beragam bidang pekerjaan serta etnis yang bekerja di dalamnya. Ditetapkannya Kota Batam sebagai salah satu kawasan free trade zone menjadikan pertumbuhan berbagai industri di Kota Batam terus meningkat, dengan adanya berbagai industri tersebut tentunya akan membutuhkan tenaga kerja yang memiliki kualitas yang tinggi. Hal tersebut terbukti dengan terus meningkatknya penduduk dari luar Pulau Batam yang masuk ke Batam, yang berasal dari berbagai daerah di Indonesia.

Penduduk yang masuk ke Kota Batam dapat diartikan sebagai tenaga kerja, yang bisa saja berasal dari Indonesia atau disebut dengan tenaga kerja lokal dan yang berasal dari luar negeri atau yang disebut dengan tenaga kerja asing. Pada dasarnya, tenaga kerja adalah 
penduduk yang sudah atau sedang bekerja, yang sedang mencari pekerjaan, dan yang melaksanakan kegiatan lain seperti bersekolah, dan mengurus rumah tangga. Berdasarkan data yang di peroleh, maka dengan ditetapkannya status free trade zone Kota Batam, tingkat tenaga kerja asing dan lokal di Kota Batam terus mengalami peningkatan, hanya saja peningkatan tersebut tidak di ikuti dengan peningkatan kualitas tenaga kerjanya.

Sumber daya manusia (SDM) yang masuk ke Pulau Batam itu pada awalnya seperti gula yang didatangi oleh semut, maksudnya adalah free trade zone adalah gula yang menjadi pemantik atau alasan bagi datangnya sekerumunan semut atau para pencari kerja yang berasal dari berbagai daerah, beragam etnis ke Pulau Batam. Hal ini tidak hanya terjadi atas masuknya tenaga kerja lokal tetapi juga alasan masuknya tenaga kerja asing.

Permasalahan sejak adanya status free trade zone dari awal ditetapkan hingga sekarang terbagi menjadi beberapa aspek. Salah satu aspek yang menjadi permasalah adalah, tidak adanya peengawasan yang ketat oleh pemerintah daerah terhadap masuknya tenaga kerja, baik lokal maupun asing ke Kota Batam, hal ini membuat terjadinya suatu kejenuhan, di mana jumlah pekerjaan yang ada tidak bisa menampung jumlah tenaga kerja yang masuk ke Pulau Batam.

Hal lain yang menjadi permasalahan utama dengan ditetapkannya status free trade zone adalah tenaga kerja asing yang masuk ke Kota Batam, memiliki kapasitas skill atau kemampuan diatas tenaga kerja lokal, bahkan berdasarkan wawancara yang dilakukan, kebanyakan tenaga kerja asing ini bekerja tidak pada jabatan rendah melainkan pada jabatan tinggi, hingga pengambil keputusan pada suatu perusahaan yang ada. Hal ini berbanding terbalik dengan kedudukan pekerja lokal yang masih berada pada tataran yang rendah. Hal ini tentunya menjadi dua bagian yang bergejolak, dimana meningkatnya tenaga kerja di Kota Batam membuat pertumbuahan ekonomi Kota Batam juga meningkat, tetapi di sisi lain hal ini juga menajdi suatu permasalahan dimana banyaknya tenaga kerja yang tidak mendapatkan pekerjaan dan memilih bertahan di kota Batam, malah menimbulkan masalah baru di kota Batam, seperti masalah sosial, kemanana, hingga ancaman bagi masyarakat, seperti tindakan kriminalitas.

\section{KESIMPULAN DAN SARAN}

Kesimpulan

1) Kondisi kota Batam dengan adanya status FTZ terus mengalami perubahanperubahan dari segi aturan hingga fasilitas yang ada, terkiat infrastruktur dan lainnya. Fasilitas bandara yang berstandar internasional, perluasan pelabuhan untuk bersandarnya kapal- kapal asing, hingga infrastruktur seperti pembangunan jalan tol dan jembatan layang, yang semuanya di persiapkan dalam rangka mendukung status FTZ kota Batam.

2) Pencapaian status FTZ kota Batam terhadap pertumbuhan ekonomi sejauh ini sudah memberikan capaian yang cukup baik, berdasarkan tiga indikator berikut: Dari segi foreign direct investment atau penanaman modal asing yang besar; dari segi indikator ekspor dan impor; dan indikator tenaga kerja.

\section{Saran}

Adapun saran peneliti, terkait status free trade zone kota Batam, dalam perspektif ekonomi pertahanan, adalah sebagai berikut;

1) Kedepannya harus ada satu payung hukum yang baku dan jelas, serta komando dari satu arah, terkait status yang tepat untuk pengembangan kota Batam. Baiknya ada pengkajian yang lebih dalam terkait fasilitas maupun infrastruktur yang akan diberikan harus sesuai dengan kondisi terkini kota Batam.

2) Capaian pertumbuhan ekonomi kota Batam dari berbagai aspek ekonomi harus disertakan ilmu pertahanan didalamnya, baik investasi, ekspor dan impor, tenaga kerja, harus dikaji bersama-sama dengan ilmu pertahanan, mengingat bentuk ancaman saat ini, bukan lagi perang tetapi ancaman dalam bentuk lain, seperti ancaman pada kedaulatan bangsa yang bisa tercipta karena adanya ketergantungan dengan investasi dari pihak asing, penyelundupan melalui sistem ekspor maupun impor, serta masuknya budayabudaya baru yang dibawa oleh tenaga kerja asing yang masuk ke Indonesia. 
DAFTAR PUSTAKA

Anwar, khairul dan Nofri Yanti. (2014). Dinamika Pelaksanaan Kawasan Perdagangan Bebas Dan Pelabuhan Bebas (Free Trade Zone) Batam. Jom FISIP Volume 1 No.2

Creswell, J.W. (2010). Research design: Pendekatan kualitatif, kuantitatif, dan mixed. Edisi ketiga. Alih bahasa oleh Achmad Fawaid.

Jakarta: RajaGrafindo Persada Winardi, J. (2013). Manjemen Perubahan (Mangement of Change). Jakarta :Kencana

Mankiw, N. Gregory. (2006). Pengantar Ekonomi Makro Edisi 3. Jakarta: Salemba Empat.

Miles, Matthew B, et al. (2014). Qualitative Data Analysis: A Methods Sourcebook. Singapore: Sage Publication Inc.

Perubahan Status FTZ kota Batam menjadi KEK tersedia di http://www.cnnindonesia.com/ek onomi/20160314104623-92117176/pemerintah-butuh- waktu-6bulan-ubah-status- batam-jadi-kek/ diakses pada 03 Mei 2016.

Sunariyah. (2010). Pengantar Pengetahuan Pasar Modal, edisi ke enam. Yogyakarta : UPP-AMP YKPN.

Sukirno, Sadono. (2004). Makroekonomi: Pengantar Teori. Jakarta: PT. Raja Grafindo Perkasa.

Sukirno, Sadono. (2006). Ekonomi Pembangunan Proses Masalah dan Dasar Kebijakan, Cetakan Ketiga Jakarta: Kencana.

Undang- undang No.44 tahun 2007 tentang kawasan Perdagangan Bebas dan Pelabuhan Bebas

Wahyuni, Sari. (2015). Qualitative Research Method. Jakarta :Penerbit Salemba Empat Wibowo. (2008). Manajemen Perubahan.

Yealta, Den. (2015). Implikasi Free Trade Zone Terhadap Pertumbuhan Ekonomi Indonesia (Suatu Kajian Bisnis Internasional Di Provinsi Kepulauan Riau). Jurnal Transnasional, Vol. 7, No. 1

Yusgiantoro, Purnomo. (2014). Ekonomi Pertahanan Teori dan Praktik. Jakarta: Gramedia Pustaka Utama.

Zaenuddin, Muhammad. (2012). Kajian Free Trade Zone (FTZ) Batam- Bintan-
Karimun (Permasalahan, Implementasi, danSolusinya). Eko- Regional, Vol. 7, No. 2 